\title{
TNP-470, a Potent Angiogenesis Inhibitor, Amplifies Human T Lymphocyte Activation through an Induction of Nuclear Factor- $\kappa$ B, Nuclear Factor-AT, and Activation Protein-1 Transcription Factors
}

\author{
Roberto Locigno, Nadine Antoine, Vincent Bours, Marc Daukandt, Ernst Heinen, \\ and Vincent Castronovo \\ Metastasis Research Laboratory (RL, MD, VC), Laboratory of Human Histology (NA, EH), and Laboratory of Medical \\ Oncology and Medical Chemistry (VB), University of Liège, Belgium
}

\begin{abstract}
SUMMARY: TNP-470, an angiogenesis inhibitor derived from fumagillin, is foreseen as a promising anti-cancer drug. Its effectiveness to restrain tumor growth and its lack of major side effects have been demonstrated in several animal models and have led the drug to reach phase III clinical trials. Beside its antiangiogenesis activities, TNP-470 exhibits several effects on the immune system. We had shown previously that TNP-470 stimulated B lymphocyte proliferation through an action on T cells. In this study, we examined the cellular and molecular modifications induced by TNP-470 in normal human T lymphocytes. Transmission electron microscopic examination of PHA/TNP-470-treated T cells revealed significant morphologic modifications when compared with PHA-treated control T cells. TNP-470 induced indeed an important and significant increase of the nuclear size as well as major nuclear chromatin decondensation. This observation indicated that TNP-470 amplified T-cell activation and led us to investigate its effects on the activation of transcription factors involved in T-cell activation. Using electrophoretic mobility shift assays, we have demonstrated that TNP-470 amplifies and extends the DNA-binding activity of nuclear factor-AT, nuclear factor $-\kappa \mathrm{B}$, and activation protein-1 in T cells. Furthermore, the angioinhibin significantly increased the secretion of IL-2 and IL-4. Our data demonstrate that TNP-470 amplifies the activation of T cells. This effect, whose molecular mechanisms remain to be elucidated, has to be taken into account in the assessment of the antitumor effect of the drug. (Lab Invest 2000, 80:13-21).
\end{abstract}

A $t$ the end of this century, antiangiogenic therapy appears as one of the most promising strategies to restrain tumor growth and prevent metastasis (Brem and Folkman, 1993; McNamara et al, 1998; Takamiya et al, 1993; Weidner et al, 1991; Yanase et al, 1993). TNP-470 is one of the several angiogenesis inhibitors currently under intense investigation in clinical trials. This synthetic analog of the fungal metabolite fumagillin is a potent proliferation inhibitor of a variety of capillaries and large vessel endothelial cells (Ingber et al, 1990; Kusaka et al, 1994). TNP-470 restrains angiogenesis in several in vivo models such as the chick chorioallantoic membrane (Kusaka et al, 1991) and the rat or rabbit cornea assays (Yamaoka et al, 1993; Yanase et al, 1993). More importantly, TNP470 significantly inhibits the growth of various experimental murine tumors (Castronovo and Belotti, 1996).

Beside its well-characterized antiangiogenic activities, TNP-470 seems also to affect the immune system (Berger et al, 1993; Hasuike et al, 1997; Schoof et al, 1993). We have reported that TNP-470 stimulates the proliferation of human (Antoine et al, 1995) and murine

Received May 28, 1999.

Address reprint requests to: Vincent Castronovo, $M D, P h D$, Metastasis Research Laboratory, University of Liege, Tour de Pathologie, -1, Bât. B23, Sart Tilman via 4000 Liège, Belgium. Fax: 32-4-3662975.
(Antoine et al, 1996a, 1996b) B lymphocytes. This effect required the presence of PHA-activated T cells and a direct contact between $B$ and $T$ cells. These results were also observed in vivo. Subcutaneous or intraperitoneal injections of TNP-470 into mice induced a significant hyperplasia of the germinal centers of axillary and mesenteric lymph nodes in normal mice but not in T lymphocyte-deficient mice (Antoine et al, 1996a). Taken together, these results suggest that the effect of TNP-470 on B cells could be mediated by a direct activation of $\mathrm{T}$ cells.

T lymphocyte activation has been extensively investigated (Alberola-Ila et al, 1997; Lanzavecchia, 1997; Zhao and Koretzky, 1997). In the nucleus, this process starts by the induction of transcription factors that allow transcription of "early activation genes," such as cytokine genes. For example, the T-cell-restricted nuclear factor of activated T cell (NF-AT) binds to one site of the IL-2 gene enhancer (Go and Miller, 1992; Shaw et al, 1988). It is composed of a pre-existing cytosolic subunit called NF-AT . During activation, $\mathrm{NF}-\mathrm{AT}_{\mathrm{p}}$ is translocated into the nucleus where it combines with an inducible nuclear subunit formed by Fos and Jun proteins (Rao, 1994; Rao et al, 1997). IL-2 gene transcription is also dependant on the ubiquitous nuclear factors NF- $\kappa \mathrm{B}$ and AP-1 (Go and Miller, 1992). The active forms of NF- $\kappa \mathrm{B}$ are dimers composed of 
different combinations of the members of the Rel/ $\mathrm{NF}-\kappa \mathrm{B}$ family of proteins (Siebenlist et al, 1994). The activation protein-1 (AP-1) is composed of different associations of proteins belonging to the Jun and Fos families (Angel and Karin, 1991).

In the present work, we have examined the effect of TNP-470 on PHA-activated T lymphocytes both at the morphologic level using electron microscopy analysis and at the molecular level through DNA gel shift analysis looking at the activation of NF- $\kappa \mathrm{B}, \mathrm{NF}-\mathrm{AT}$, and $\mathrm{AP}-1$ transcription factors. We also investigated the effect of this drug on the T-cell secretion of two major cytokines: IL-2 and IL-4.

\section{Results}

\section{TNP-470 Induces Significant Ultrastructural Modifications} in PHA-Activated T Lymphocytes

T lymphocytes activated with PHA were treated or not by TNP-470 and examined by transmission electron microscopy to detect possible morphologic modifications. Figure $1 \mathrm{~A}$ shows a representative microphotograph of control T cells treated with PHA $(4 \mu \mathrm{g} / \mathrm{ml})$ and $0.1 \%$ dimethyl sulfoxide (DMSO; vehicle of TNP-470). A majority of cells appeared in an activated status, as suggested by the decondensation of chromatin and the presence of large nucleoli. These two phenomena were dramatically amplified when PHA-activated T cells were treated with TNP-470. As shown in Figure $1 \mathrm{~B}$, the chromatin of the $\mathrm{T}$ cells was fully decondensed, and the sizes of the cells and their nuclei were increased. These observations were quantified by morphometrical analysis. Six hundred thirty-three control T cells and 571 TNP-470-treated T cells were manually delineated to measure cell and nucleus sizes. The cell and nucleus surfaces of TNP-470treated cells were significantly increased compared with control cells (Table 1). We also found that TNP470-treated cells have a nucleus/cell surface ratio significantly decreased compared with control cells. No morphologic changes were observed when $T$ cells were treated with TNP-470 only (data not shown).

\section{TNP-470 Increases and Prolongs the DNA-Binding Activities of PHA-Induced Transcription Factors}

Because nuclear activity seems to be generally amplified in the presence of TNP-470, we investigated whether the drug had an influence on transcriptional factors known to be involved in T-cell activation. Electrophoretic mobility shift assays (EMSA) were performed to examine the DNA-binding activities of three important transcription factors in nuclear extracts from TNP-470-treated T lymphocytes: NF-AT, $\mathrm{NF}-\kappa \mathrm{B}$, and $\mathrm{AP}-1$. Nuclear extracts were prepared from cells treated with PHA, TNP-470, or PHA+TNP470. Untreated cells were used as controls. EMSA performed with an oligonucleotide containing a NFAT-binding site revealed a rapid induction of this nuclear factor when the cells were treated with PHA alone (Fig. 2A, lanes 2-4). This induction decreased after 4 hours (lane 3 ) and disappeared completely after
24 hours (lane 4). Although treatment with TNP-470 alone had no effect on NF-AT-binding activity (lanes 5-7), combined treatment with PHA and TNP-470 increased NF-AT nuclear induction. For each transcription factor investigated, the specificity of the bands observed was demonstrated by competition with an excess of unlabeled probe, using nuclear extracts from the cells treated with PHA+TNP-470 for 1 hour (compare lanes 8 and "comp"). Additionally, when the competition was carried out using oligonucleotides in which the protein-binding site was mutated (see "Materials and Methods"), there was no inhibition in the formation of the corresponding protein/DNA complexes (data not shown). Interestingly, similar experiments using oligonucleotides containing $\mathrm{NF}-\kappa \mathrm{B}$ (Fig. 2B) and AP-1 (Fig. 2C) binding sites revealed stronger induction of DNA binding in cells treated with PHA+TNP-470 as compared with cells stimulated with PHA alone. In both cases, this activation was prolonged in the presence of the two drugs. These data were quantitatively evaluated by densitometric analysis. As shown in Figure $3(A-C)$, the binding activity of the three transcription factors investigated is increased compared with control cells.

\section{TNP-470 Increases Secretion of IL-2 and IL-4 by PHA-Activated T Lymphocytes}

Because T-cell activation and nuclear factor induction result in cytokine production, we investigated whether TNP-470 could stimulate IL-2 and IL-4 secretion. We cultured human $\mathrm{T}$ lymphocytes in the presence of TNP-470 (500 pg/ml) and/or PHA ( $4 \mu \mathrm{g} / \mathrm{ml})$ for 48 and 72 hours. Culture supernatants were analyzed by ELISA for IL-2 and IL-4 secretion as described in "Materials and Methods." Because PHA activation clearly stimulated IL-2 and IL-4 production, the addition of TNP-470 induced a further increase in the secretion of both cytokines (Fig. 4).

\section{Discussion}

In this study, we demonstrated that the angioinhibin TNP-470 significantly amplifies the activation of $T$ lymphocytes. Transmission electron microscopy and morphometrical analysis showed that PHA-activated $\mathrm{T}$ cells treated with TNP-470 exhibit a dramatic increase in cell size due to an increase of both the cytosol and the nucleus. Bigger nucleoli and extensive chromatin decondensation indicate that the drug affects T-cell activation. Interestingly, TNP-470 was ineffective when added to $T$ cells that were not preactivated with PHA. This observation suggests that the angioinhibin affects the activation process once it has been triggered but is not able to initiate it.

The morphologic effect induced by TNP-470 was associated with a prolonged and increased induction of three major transcription factors largely involved in T-cell activation: NF-AT, NF- $\kappa$ B, and AP-1. Direct interactions occur between transcription factors and are essential for appropriate DNA binding and transactivation. Indeed, NF-AT, $\mathrm{AP}-1$, and $\mathrm{NF}-\kappa \mathrm{B}$ are 


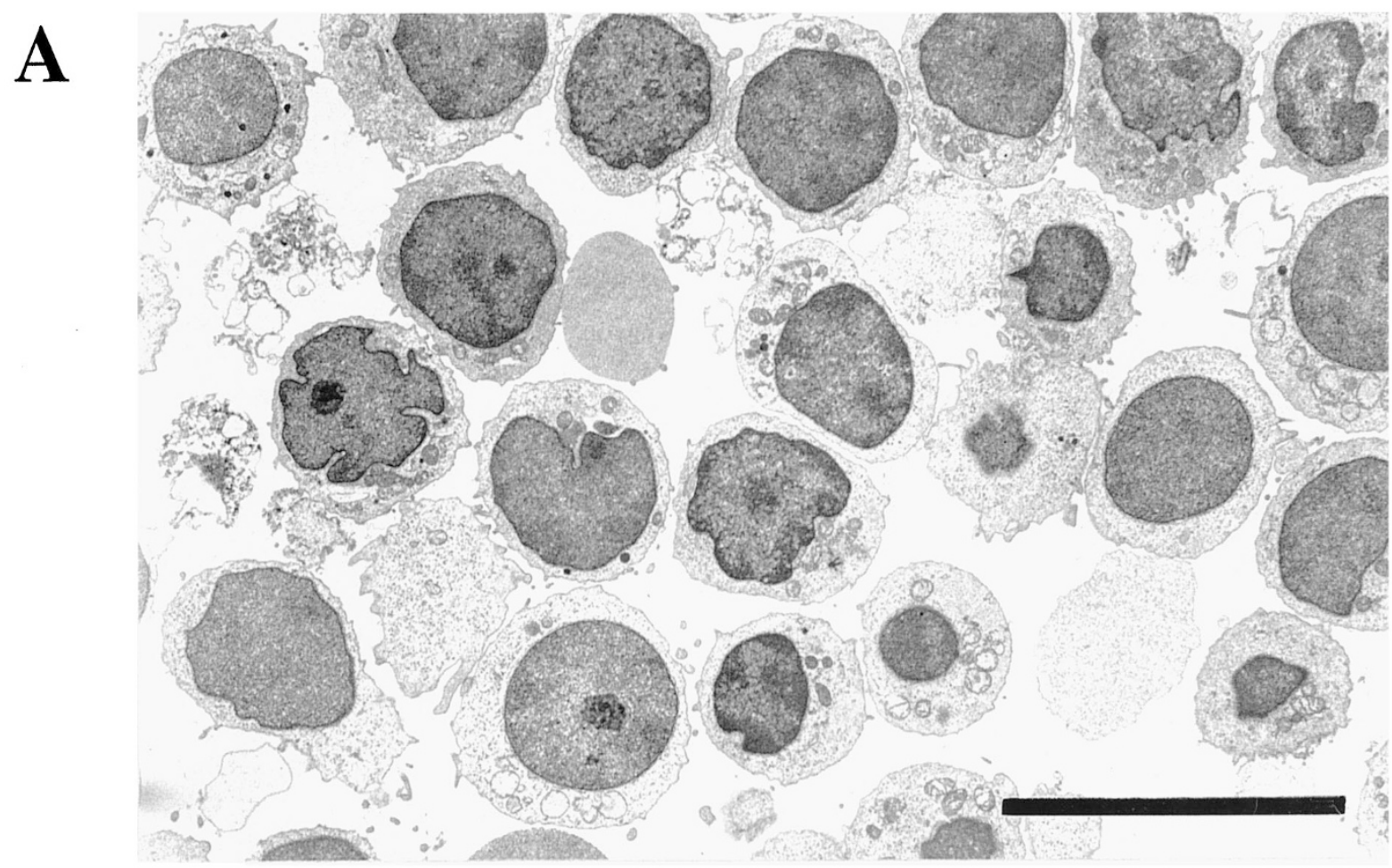

B

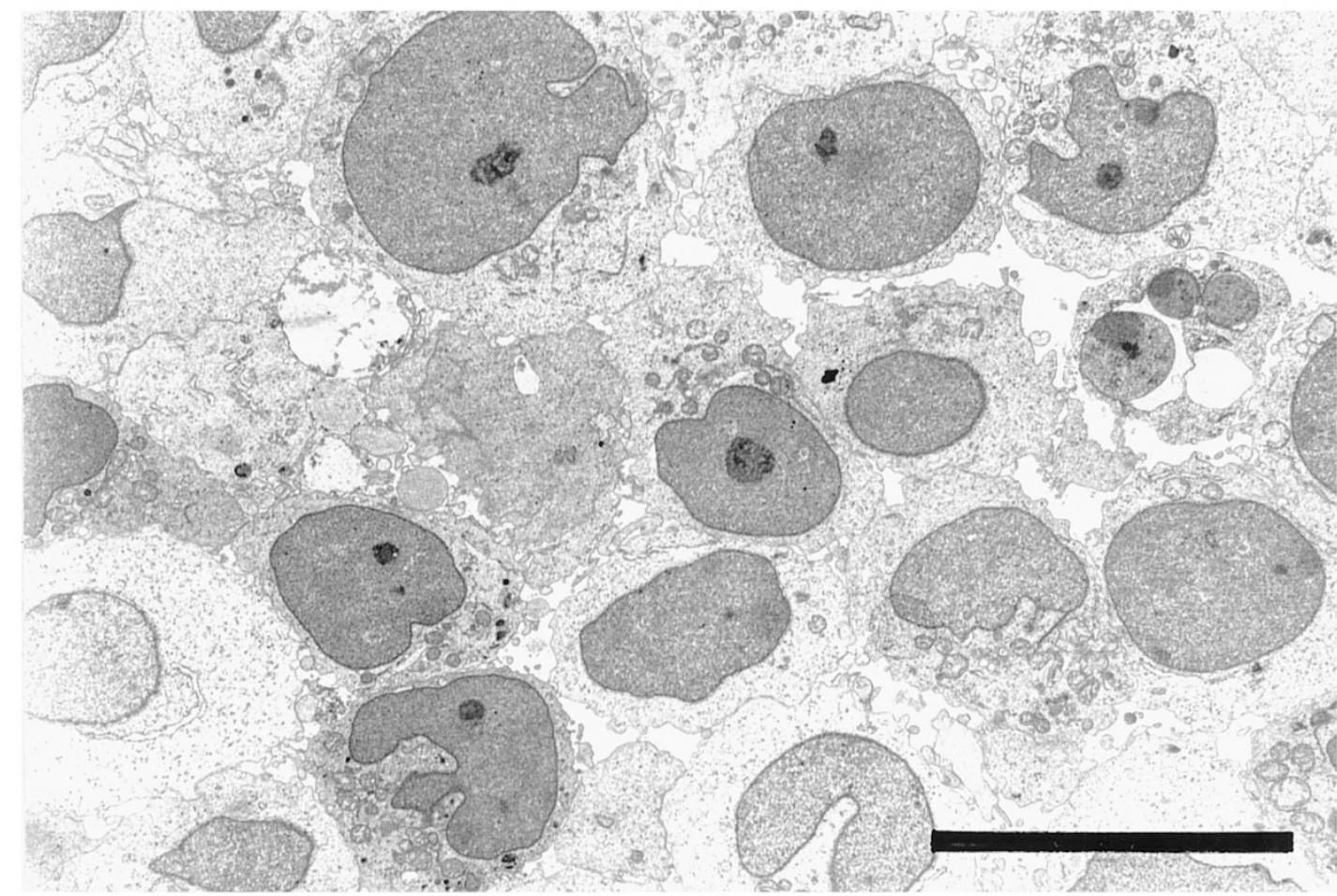

\section{Figure 1.}

Transmission electron micrographs of human T lymphocytes. (A) T cells treated for 48 hours with PHA $(4 \mu \mathrm{g} / \mathrm{ml})$ and $0.1 \%$ DMSO (vehicle of TNP-470), used as controls. (B) T cells treated for 48 hours with PHA $(4 \mu \mathrm{g} / \mathrm{ml})$ and TNP-470 $(500 \mathrm{pg} / \mathrm{ml})$. Black lines represent $10 \mu \mathrm{m}$.

thought to interact in order to realize proper transcription initiation (Angel and Karin, 1991; Jain et al, 1992; Rao, 1994; Siebenlist et al, 1994). Our data suggest that TNP-470 may act on a common pathway of cell activation. Consistently, no effect on NF-AT, NF- $\kappa$ B, and AP-1 activity was observed when non-PHAtreated $T$ cells were incubated with TNP-470.

Although the exact mechanism of action of lectins on T lymphocytes remains unclear, they are thought to mimic the effect of the physiologic interaction of an 
Table 1. Morphometric Analysis of PHA-activated T Cells Treated or Not with TNP-470

\begin{tabular}{cccc}
\hline & Cell surface & Nucleus surface $^{*}$ & Nucleus/cell \\
\hline PHA+DMSO & $23.447(7.351)$ & $11.084(1.991)$ & $0.488(0.113)$ \\
PHA+TNP-470 & $36.447(14.546)$ & $14.241(6.475)$ & $0.389(0.117)$ \\
$\mid$ Z & 19.3 & 11.2 & 14.9 \\
\hline
\end{tabular}

The values are expressed in square micrometers and represent the means obtained from 633 control cells and 571 TNP-470-treated cells. Standard deviations are indicated between parentheses.

antigen with the TCR (Bemer et al, 1995; Peacock et al, 1990). Interactions between a ligand and the TCR are followed by activation of different enzymes belonging to the src and syk families of protein tyrosine kinases (Alberola-lla et al, 1997). The activity of these protein tyrosine kinases allows the development of two different cascades of events. Firstly, guanosine triphosphate-binding proteins (ras, rac, rho. . . ) could be recruited to control a series of serine/threonine kinase cascades (mitogen-activated protein kinase cascades). Secondly, activation of phospholipase C could generate intracellular calcium mobilization and subsequent activation of protein kinase C. All these events converge to final effectors, ie, transcription factors, permitting the development of the cell response (in this case, proliferation and cytokine production). Interestingly, the activation of NF-AT seems to be dependent on the calcium pathway (Masuda et al, 1998; Rao et al, 1997). Indeed, NF-AT is translocated into the nucleus after the action of the calciumdependent phosphatase calcineurin. This fact is confirmed by the dramatic negative effect of cyclosporine A (CsA) on the activation of NF-AT (Flanagan et al, 1991), because it is now well accepted that CsA inhibits the phosphatase activity of calcineurin (Crabtree and Clipstone, 1994). Activation of NF- $\kappa \mathrm{B}$ could also depend on intracellular calcium elevation because its binding activity is affected by CsA (Schmidt et al, 1990). Taken together, these data suggest that TNP-470 could act at an early point of the transduction pathway.

Recently, a mechanism of action of TNP-470 on endothelial cells have been suggested (Griffith et al, 1998; Sin et al, 1997). Indeed, TNP-470 and fumagillin are able to bind covalently to the type 2 methionine aminopeptidase (Met AP-2), a metalloprotease involved in activation of proteins by myristoylation (binding of myristic acid on $\mathrm{N}$-terminal glycine residues). This covalent interaction results in inactivation of Met AP-2. In T cells, Met AP-2 is involved in the regulation of src proteins (Peseckis et al, 1993), suggesting that TNP-470 would exert an inhibitory effect on the early events of activation. Our results suggest that it is not the case and that another possible explanation has to be proposed. In this context, recent data, showing that the redox status of the cell plays a role in NF- $\kappa \mathrm{B}$ activation during the immune response (Ginn-Pease and Whisler, 1998), have to be carefully considered. Indeed, T cells require two signals for full activation of $\mathrm{NF}-\kappa \mathrm{B}$. First, a cascade of events mediated by TCR/ CD3 stimulation and, next, an activation pathway mediated by CD28 or tumor necrosis factor- $\alpha$ receptor stimulation and subsequent production of $\mathrm{H}_{2} \mathrm{O}_{2}$ and reactive oxygen species. Interestingly, the numerous reactions in which these very reactive compounds are implied could also be encountered in the cytoplasm of cells presenting a nitric oxide (NO) overproduction (Wink et al, 1998). In normal conditions, NO is produced by different isoforms of NO synthases and transported extracellularly after myristoylation and translocation of the enzyme to the caveolae of the plasma membrane (Sakoda et al, 1995). The inhibition of myristoylation by covalent reaction between TNP470 and Met AP-2 (see above) could thus suggest an explanation for the intracellular accumulation of $\mathrm{NO}$ and the subsequent modification of the $\mathrm{T}$-cell redox status.

We also showed that TNP-470 increases IL-2 and IL-4 secretion by PHA-treated T cells. These data are in agreement with the transcription factor activation observed in this study because IL-2 gene transcription is known to be dependant on NF- $\kappa \mathrm{B}, \mathrm{NF}-\mathrm{AT}$, and AP-1 (Crabtree and Clipstone, 1994). For IL-4, a recent review by Szabo et al (1997) suggests a role of NF-AT and AP-1 in the control of gene transcription.

In conclusion, we have demonstrated that TNP-470 amplifies and extends the T-cell activation induced by PHA. Our data explain, at least in part, the significant increase of $B$ lymphocyte proliferation in the presence of PHA/TNP-470-treated T lymphocytes. This activity of TNP-470 may be important in the therapeutic evaluation of this drug. In addition to its antiangiogenic activities, TNP-470 could play a role in strengthening the efficacy of the immune system to fight the cancer cells. Additional studies need to be performed to demonstrate such an effect and to elucidate the exact mechanisms by which TNP-470 amplifies T-cell activation. Finally, our data identify TNP-470 as a useful tool to study the molecular mechanisms that are involved during T-cell activation.

\section{Materials and Methods}

\section{T Lymphocyte Purification}

Human T lymphocytes were obtained from the peripheral blood of healthy donors, kindly collected by the "Croix Rouge de Belgique" (University Hospital, Liège, Belgium). Blood lymphocytes were purified by FicollHypaque (Pharmacia Biotech, Uppsala, Sweden) density gradient centrifugation as described previously (Baijum, 1968). The T-cell population was obtained by rosetting with 2-aminoethylisothiouronium bromide (Sigma-Aldrich, Bornem, Belgium)-treated sheep 

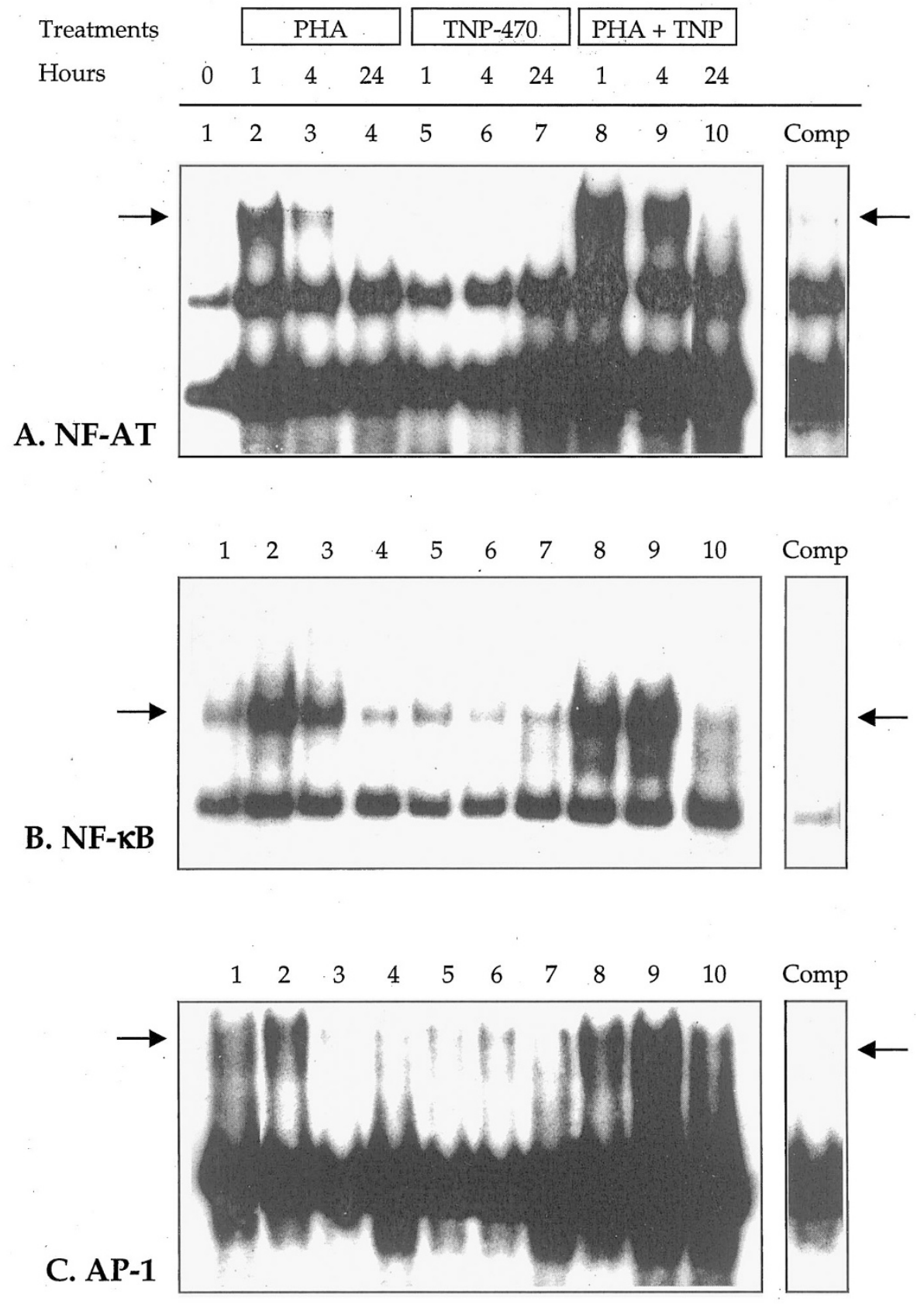

\section{Figure 2.}

TNP-470 amplifies and extends the DNA-binding activity of NF-AT (A), NF- $\kappa$ B (B), and AP-1 (C) in PHA-activated T cells. DNA-protein complexes were formed between the corresponding ${ }^{32} \mathrm{P}$-end-labeled double-stranded oligonucleotides and nuclear extracts from cells treated for 1, 4, or 24 hours with PHA (4 $\mu \mathrm{g} / \mathrm{ml}$ ), TNP-470, (500 $\mathrm{pg} / \mathrm{ml}$ ), or with PHA+TNP-470 as described in "Materials and Methods." Untreated cells were considered as controls (lane 1). The arrows indicate specific bands inhibited by the addition of unlabeled oligonucleotide for each transcription factor ("Comp" lane).

erythrocytes and centrifugation over Ficoll-Hypaque. The erythrocytes were lysed and $\mathrm{T}$ lymphocytes recovered and rinsed. The T-cell population was contaminated by approximately $10 \%$ of $\mathrm{B}$ cells, as determined by CD3/CD19 double labeling (Dako, Carpinteria, CA) and analysis using a flow cytometer (FacScan; Becton Dickinson, San Jose, CA.). The T-cell population was further purified by immunomagnetic Dynabeads (Dynal, Oslo, Norway). Briefly, the lymphocytes were incubated with anti-B cell monoclonal antibodies (CD19; Dako) and then with a second- ary anti-mouse IgG, coupled with a magnetic bead. Subsequent exposure to a magnetic field and washing steps removed the bead-coated B lymphocytes. This procedure led to a more than $96 \%$ pure T lymphocyte population, as determined by flow cytometry analysis (see above).

\section{Cell Culture}

T cells were cultured with complete RPMI medium containing $10 \%$ heat-inactivated fetal calf serum, pen- 
A. NF-AT

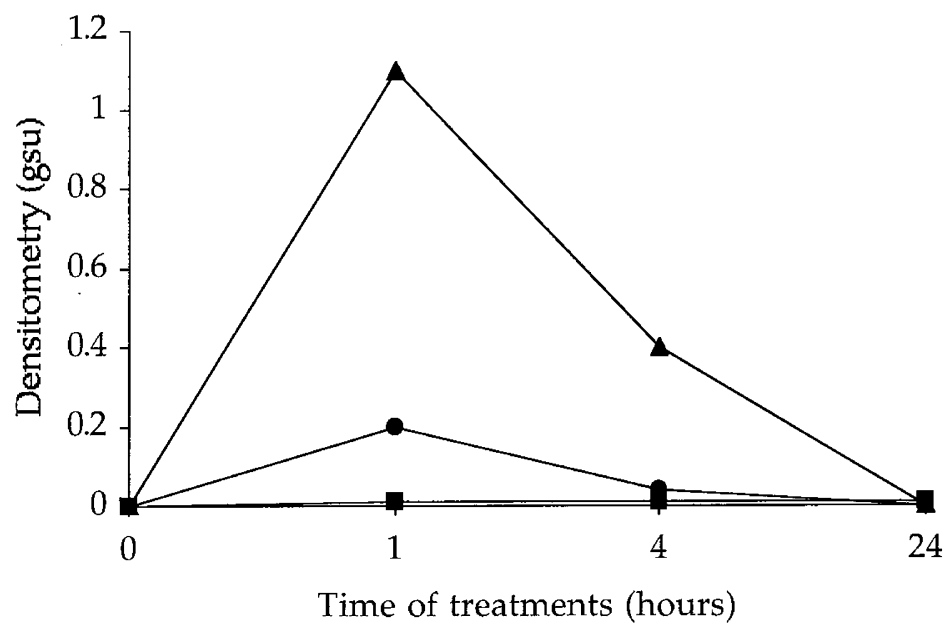

B. NF-KB

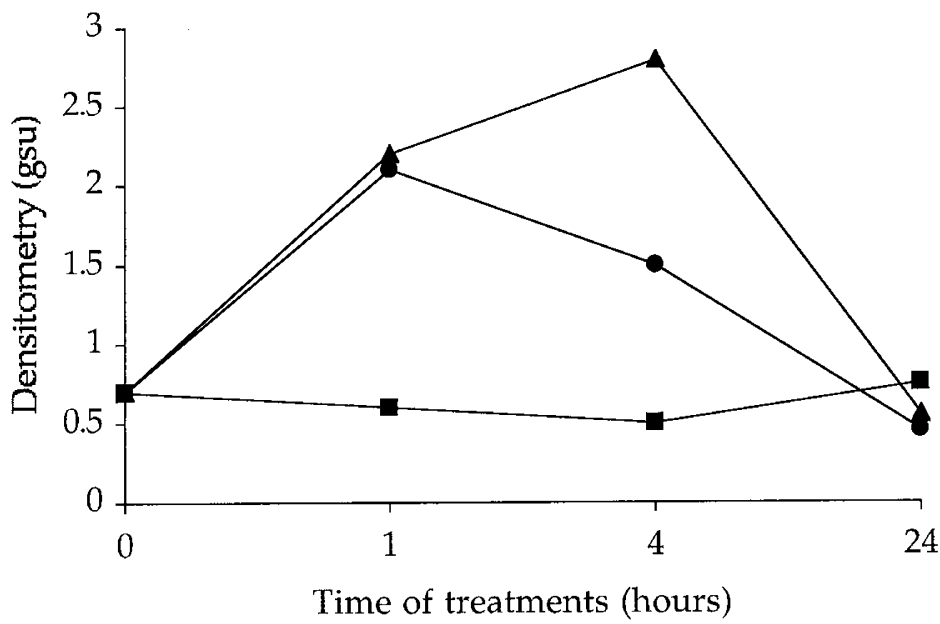

C. AP-1

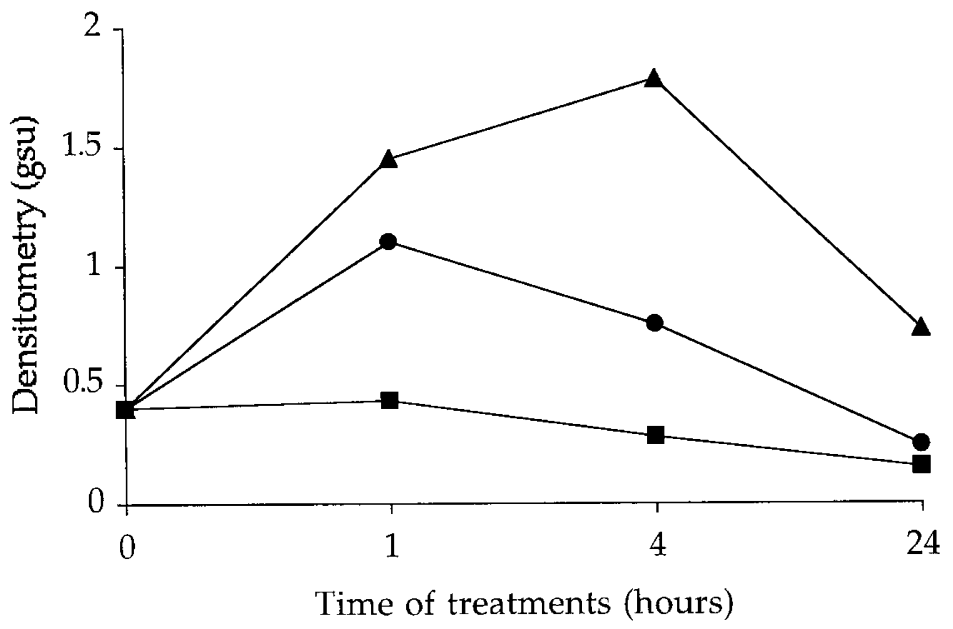

Figure 3.

Densitometry analysis of the DNA/NF-AT (A), DNA/NF- $\kappa B(B)$, and DNA/AP-1 complexes formed using nuclear proteins extracted from PHA-activated T cells treated or not by TNP-470. Densitometry values are given in multiple of $10^{6}$ "grey scale units" (gsu), which are directly proportional to optical density. The values were plotted after subtraction of background densitometry. $\mathbf{\square}=$ TNP-470 treatment; $\boldsymbol{\bullet}=$ PHA treatment; $\mathbf{\Delta}=$ TNP-470+PHA treatment. 
A1

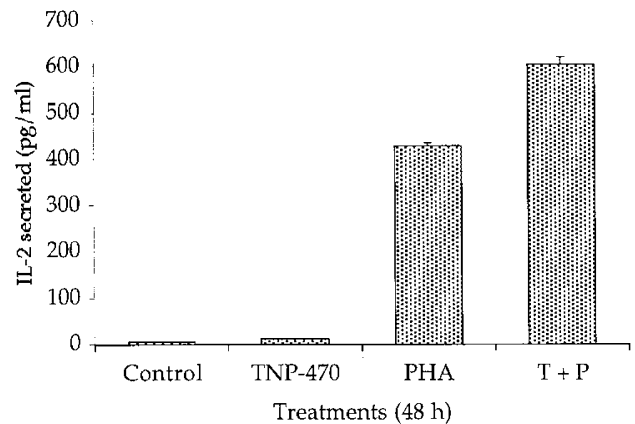

A2

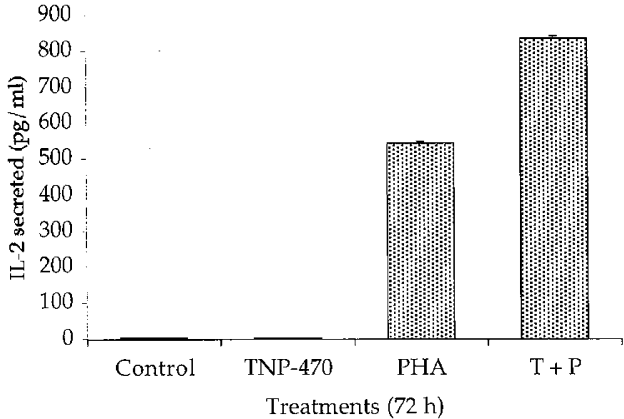

B1

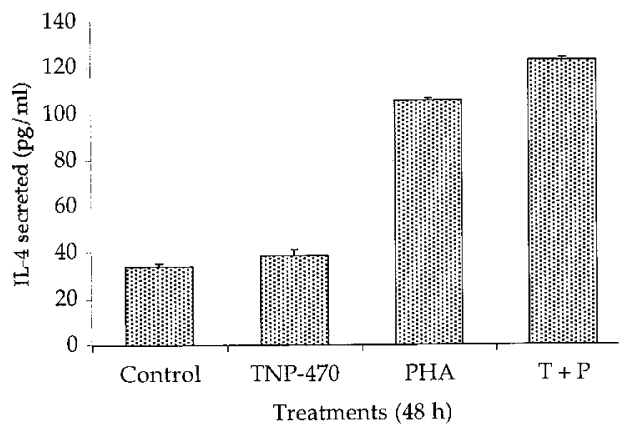

B2

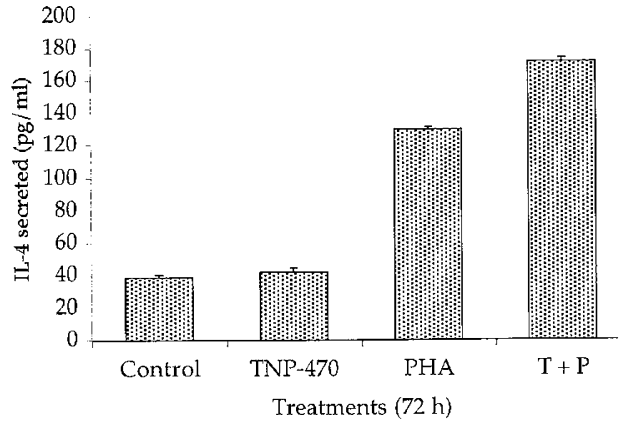

\section{Figure 4.}

TNP-470 increases secretion of IL-2 (A1 and A2) and IL-4 (B1 and B2) in PHA-activated T lymphocytes. T cells were treated 48 hours (A1 and B1) or 72 hours (A2 and B2), and cytokines were quantified in the culture supernatant as described in "Materials and Methods." In each experiment, cells were treated with TNP-470 (500 $\mathrm{pg} / \mathrm{ml})$, PHA $(4 \mu \mathrm{g} / \mathrm{ml})$, or TNP-470 + PHA (T + P). Control cells were untreated.

icillin $(200 \mathrm{U} / \mathrm{ml})$, and streptomycin $(100 \mathrm{U} / \mathrm{ml})$. Cells were incubated at $37^{\circ} \mathrm{C}$ in an atmosphere containing $5 \% \mathrm{CO}_{2}$ under saturating humidity. For electron microscopy analysis, T cells were incubated for 48 hours with $500 \mathrm{pg} / \mathrm{ml}$ TNP-470 (Takeda Chemical Industries, Ltd., Osaka, Japan) and $4 \mu \mathrm{g} / \mathrm{ml}$ PHA-L (Boehringer Mannheim, Mannheim, Germany). TNP-470 was dissolved in DMSO (with a final concentration lower than $0.1 \%$ ). For these two types of experiments, control cells were treated with PHA-L alone or with PHA-L and DMSO. For transcription factor assays, T lymphocytes were incubated in the absence or presence of TNP$470(500 \mathrm{pg} / \mathrm{ml})$ and PHA-L $(4 \mu \mathrm{g} / \mathrm{ml})$ for 1,4 , and 24 hours. For ELISA tests, $T$ lymphocytes were left untreated or were incubated for 48 hours and 72 hours with TNP-470 (500 pg/ml) and/or PHA-L $(4 \mu \mathrm{g} / \mathrm{ml})$. Controls were untreated cells.

\section{Transmission Electron Microscopy}

T lymphocytes were fixed with glutaraldehyde $2.5 \%$ in cacodylate buffer $\left(\mathrm{pH} 7.2,30\right.$ minutes at $\left.4^{\circ} \mathrm{C}\right)$. They were rinsed in the same buffer and postfixed in $2 \%$ osmium in cacodylate buffer for 30 minutes, at $4^{\circ} \mathrm{C}$. Cells were then progressively rehydrated, rinsed in distilled water, and embedded in Epon. Ultrathin sections $(60 \mathrm{~nm})$ performed using a Reichert microtome (Philips E-M201, Eindhoven, The Netherlands) were contrasted with aronyl acetate (15 minutes) and lead citrate (15 minutes) as previously described (Reynolds,
1963). Sections were observed using an electron microscope (Philips E-M 201; ).

\section{Morphometric Analysis}

Control PHA-L-treated T-cell areas were compared with $T$ cells treated for 48 hours with PHA-L and TNP-470 at a concentration of $500 \mathrm{pg} / \mathrm{ml}$. T-cell areas were measured with a computerized IBAS 2000 image analyzer (Kontron, Eching, Germany) and expressed in square micrometers. These data were statistically analyzed according to a parametric unpaired comparison of the means. A large number of cells was chosen for each condition (633 for control and 571 for treated cells). The means of the two conditions were compared for each case (cell surface, nucleus surface, and nucleus/cell ratio) by the calculation of " $Z$ " value as follows:

$Z=\left(\mu_{\text {control }}-\mu_{\text {AGM }}\right) / \sqrt{ }\left(\left(s^{2}{ }_{\text {control }} / 633\right)+\left(s^{2}{ }_{\text {AGM }} / 571\right)\right)$,

where $\mu=$ mean and $\mathbf{s}=$ standard deviation. When $|Z|$ is $>=1.96$, the difference between the means is significant, considering an error risk of $5 \%$.

\section{Nuclear Extracts and Mobility Shift Assays}

Nuclear extracts were prepared from about $2 \times 10^{7}$ human peripheral $T$ lymphocytes. The cells were washed three times with PBS and once in $1 \mathrm{ml}$ of buffer A [10 mm HEPES, pH 7, $20 \mathrm{~mm} \mathrm{KCl,} 2$ mm 
$\mathrm{MgCl}_{2}, 0.1 \mathrm{~mm}$ EDTA, $1 \mathrm{~mm}$ dithiothreitol (DTT), $1 \mathrm{~mm}$ phenylmethlysulfonyl fluoride (PMSF), proteases inhibitors-see below] and then incubated for $30 \mathrm{sec}-$ onds at $4^{\circ} \mathrm{C}$ in $1 \mathrm{ml}$ of buffer $\mathrm{B}$ (buffer A plus $0.2 \%$ Nonidet $\mathrm{P}-40$ and $10 \mathrm{~mm} \mathrm{KCl}$ ). Nuclei were then pelleted at $6000 \mathrm{rpm}$ for 5 minutes. Pelleted nuclei were washed twice with $500 \mu \mathrm{l}$ of buffer A. Two volumes of buffer $\mathrm{C}$ (20 mm HEPES, $\mathrm{pH} 7.9,1.5 \mathrm{~mm}$ $\mathrm{MgCl}_{2}, 0.2 \mathrm{~mm}$ EDTA, $0.63 \mathrm{~mm} \mathrm{NaCl}, 25 \%$ glycerol, 0.5 mM DTT, $1 \mathrm{~mm}$ PMSF, and proteases inhibitors-see below) were added to the resulting pellet. After mixing on a rotating table for 30 minutes, the viscous solution was centrifuged at $14000 \mathrm{rpm}$ for 30 minutes. The supernatants containing nuclear proteins were saved at $-70^{\circ} \mathrm{C}$ until use. Concentrations of proteins were determined by the BioRad Protein Assay (BioRad Laboratories, Hercules, CA). Buffers A, B, and C contain protease inhibitors (Boehringer Mannheim) as follows: $74 \mu \mathrm{M}$ antipain, $1 \mu \mathrm{M}$ leupeptin, $1 \mu \mathrm{M}$ pepstatin, $0.3 \mu \mathrm{M}$ aprotinin, $130 \mu \mathrm{M}$ bestatine, $0.17 \mu \mathrm{M}$ chymostatine, $28 \mu \mathrm{m}$ E-64, and $4 \mathrm{~mm}$ Pefabloc. EMSA were performed as described (Bressler et al, 1991).

Binding reactions were carried out in a solution containing $3 \mu \mathrm{g}$ of poly(dl)poly(dC) (Pharmacia Biotech, Piscataway, NJ), $1 \mu \mathrm{g}$ of bovine BSA, $2 \mu \mathrm{g}$ of nuclear proteins, and an adequate volume of buffer $D$ (20 mм HEPES, 10 mм KCl, 0.2 mм EDTA, 0.5 mм DTT, $0.5 \mathrm{~mm}$ PMSF, and $20 \%$ glycerol) to bring the volume of the reaction to $20 \mu \mathrm{l}$. The mixture was then incubated for 30 minutes at room temperature. When a competition was made to test the specificity of the binding reaction, a 50-fold excess of unlabeled corresponding probe was added before adding the nuclear proteins. Additional controls include competition with an excess of mutated oligonucleotides for each transcription factors studied. The probe for NF- $\kappa \mathrm{B}$ was derived by annealing oligonucleotides $5^{\prime}$-ttggAAGGAGAGGGGATTCCCCTGCCGTTG-3' and 5'-ttggCAACGGCAGGGAATCCCCTCTCCTT-3', whereas the mutated probe was obtained after annealing oligonucleotides 5'-ttggACCGATCGCTCATTGTGCTGAGGTTG-3' and 5' 'ttggCAACCTCAGCACAATGAGCGATCGGT-3'. The probe for AP-1 was derived by annealing oligonucleotides 5'-gatcTCATGACTCAGAGGAAAAC-3' and 5' -tcgaGTITTCCTCTGAGTCATGA-3', whereas the mutated probe was obtained after annealing oligonucleotides 5'-gatcTCGCGAAGCATCGGCGATC-3' and 5'-gatcGATCGCCGATGCTTcgCGA-3'. The probe for NF-AT was derived by annealing oligonucleotides 5'-ggttGTATGAAACAGTTTTTCCTCCTT-3' and 5'ggttAAGGAGGAAAAACTGTTTCATAC-3', whereas the mutated probe was obtained after annealing oligonucleotides $5^{\prime}$-ggttAAGGAGGCAAAACTGTTGCATAC-3' and 5' ${ }^{\prime}$-ggttGTATGCAACAGTTTTGCCTCCTT-3'. The samples were subjected to electrophoresis at room temperature in $4 \%$ polyacrylamide gels in 0.25X TBE (90 mm Tris, $90 \mathrm{~mm}$ boric acid, 2 mm EDTA, pH 8.0) followed by autoradiography. Each experiment was repeated at least two times.

\section{Densitometry Analysis}

Autoradiographies resulting from EMSA were scanned. The relative densitometry of each band was evaluated using the Scan Analysis software from Apple Computer, Inc. (Cupertino, CA).

\section{Quantification of Secreted IL-2 and IL-4 by ELISA}

After 48 or 72 hours of treatment (see above), IL-2 and IL-4 concentrations were measured in the T-cell culture supernatants by ELISA, using Predicta Elisa Kits (Genzyme, Cambridge, MA).

\section{Acknowledgements}

This work was supported by the "Association Contre le Cancer," the "Association Sportive Contre le Cancer," the "Fondation Leon Frederick," and the "Centre anticancereux pres l'Universite de Liege" (Belgium). Morphometrical analyses were performed in the Laboratory of Hematology (Professor J.M. Paulus), Faculty of Medicine, University of Liege, Belgium.

\section{References}

Alberola-lla J, Takaki S, Kerner JD, and Perlmutter RM (1997). Differential signaling by lymphocyte antigen receptors. Annu Rev Immunol 15:125-154.

Angel P and Karin M (1991). The role of Jun, Fos and the AP-1 complex in cell-proliferation and transformation. Biochim Biophys Acta 1072:129-157.

Antoine N, Bours V, Heinen E, Simar LJ, and Castronovo V (1995). Simulation of human B-lymphocyte proliferation by AGM-1470, a potent inhibitor of angiogenesis. J Natl Cancer Inst 87:136-139.

Antoine N, Daukandt M, Heinen E, Simar LJ, and Castronovo V (1996a). In vitro and in vivo stimulation of the murine immune system by AGM-1470, a potent angiogenesis inhibitor. Am J Pathol 148:393-398.

Antoine N, Daukandt M, Locigno R, Heinen E, Simar LJ, and Castronovo V (1996b). The potent angioinhibin AGM-1470 stimulates normal but not human tumoral lymphocytes. Tumori 82:27-30.

Baijum A (1968). Isolation of mononuclear cells and granulocytes from human blood. Scand J Clin Lab Invest Suppl 21:77-89.

Bemer V, Rovira P, and Truffa-Bachi P (1995). T-cell activation, anergy and immunomodulation by molecules of viral, fungal and vegetal origin. Res Immunol 146:249-262.

Berger AE, Dortch KA, Staite ND, Mitchell MA, Evans BR, and Holm MS (1993). Modulation of T lymphocyte function by the angiogenesis inhibitor AGM-1470. Agents Actions $39 \mathrm{Spec}$ No:C86-C88.

Brem $\mathrm{H}$ and Folkman $\mathrm{J}$ (1993). Analysis of experimental antiangiogenic therapy. J Pediatr Surg 28:445-450; discussion 450-451.

Bressler P, Pantaleo G, Demaria A, and Fauci AS (1991). Anti-CD2 receptor antibodies activate the HIV long terminal repeat in T lymphocytes. J Immunol 147:2290-2294. 
Castronovo V and Belotti D (1996). TNP-470 (AGM-1470): Mechanisms of action and early clinical development. Eur $\mathrm{J}$ Cancer 32A:2520-2527.

Crabtree GR and Clipstone NA (1994). Signal transmission between the plasma membrane and nucleus of $\mathrm{T}$ lymphocytes. Annu Rev Biochem 63:1045-1083.

Flanagan WM, Corthesy B, Bram RJ, and Crabtree GR (1991). Nuclear association of a T-cell transcription factor blocked by FK-506 and cyclosporin A (See comments). Nature 352:803-807.

Ginn-Pease ME and Whisler RL (1998). Redox signals and NF-kappaB activation in T cells. Free Radic Biol Med 25: 346-361.

Go C and Miller J (1992). Differential induction of transcription factors that regulate the interleukin 2 gene during anergy induction and restimulation. J Exp Med 175:1327-1336.

Griffith EC, Su Z, Niwayama S, Ramsay CA, Chang YH, and Liu JO (1998). Molecular recognition of angiogenesis inhibitors fumagillin and ovalicin by methionine aminopeptidase 2 . Proc Natl Acad Sci USA 95:15183-15188.

Hasuike T, Hino M, Yamane T, Nishizawa $Y$, Morii $H$, and Tatsumi N (1997). Effects of TNP-470, a potent angiogenesis inhibitor, on growth of hematopoietic progenitors (Letter). Eur J Haematol 58:293-294.

Ingber D, Fujita T, Kishimoto S, Sudo K, Kanamaru T, Brem $\mathrm{H}$, and Folkman J (1990). Synthetic analogues of fumagillin that inhibit angiogenesis and suppress tumour growth. Nature 348:555-557.

Jain J, McCaffrey PG, Valge-Archer VE, and Rao A (1992). Nuclear factor of activated $T$ cells contains Fos and Jun. Nature 356:801-804.

Kusaka M, Sudo K, Fujita T, Marui S, Itoh F, Ingber D, and Folkman J (1991). Potent anti-angiogenic action of AGM1470: Comparison to the fumagillin parent. Biochem Biophys Res Commun 174:1070-1076.

Kusaka M, Sudo K, Matsutani E, Kozai Y, Marui S, Fujita T, Ingber D, and Folkman J (1994). Cytostatic inhibition of endothelial cell growth by the angiogenesis inhibitor TNP470 (AGM-1470). Br J Cancer 69:212-216.

Lanzavecchia A (1997). Understanding the mechanisms of sustained signaling and $\mathrm{T}$ cell activation (comment). J Exp Med 185:1717-1719.

Masuda ES, Imamura R, Amasaki Y, Arai K, and Arai N (1998). Signalling into the T-cell nucleus: NFAT regulation. Cell Signal 10:599-611.

McNamara DA, Harmey JH, Walsh TN, Redmond HP, and Bouchier-Hayes DJ (1998). Significance of angiogenesis in cancer therapy. Br J Surg 85:1044-1055.

Peacock JS, Colsky AS, and Pinto VB (1990). Lectins and antibodies as tools for studying cellular interactions. J Immunol Methods 126:147-157.

Peseckis SM, Deichaite I, and Resh MD (1993). lodinated fatty acids as probes for myristate processing and function: Incorporation into pp60v-src. J Biol Chem 268:5107-5114.

Rao A (1994). NF-ATp: A transcription factor required for the co-ordinate induction of several cytokine genes. Immunol Today 15:274-281.
Rao A, Luo C, and Hogan PG (1997). Transcription factors of the NFAT family: Regulation and function. Annu Rev Immunol 15:707-747.

Reynolds (1963). The use of aronyl acetate and lead citrate in the preparation of ultrathin sections for electron microscopy. J Cell Biol 17:208-212.

Sakoda T, Hirata K, Kuroda R, Miki N, Suematsu M, Kawashima S, and Yokoyama M (1995). Myristoylation of endothelial cell nitric oxide synthase is important for extracellular release of nitric oxide. Mol Cell Biochem 152:143-148.

Schmidt A, Hennighausen L, and Siebenlist U (1990). Inducible nuclear factor binding to the kappa B elements of the human immunodeficiency virus enhancer in $T$ cells can be blocked by cyclosporin $\mathrm{A}$ in a signal-dependent manner. J Virol 64:4037-4041.

Schoof DD, Obando JA, Cusack JC Jr, Goedegebuure PS, Brem $\mathrm{H}$, and Eberlein TJ (1993). The influence of angiogenesis inhibitor AGM-1470 on immune system status and tumor growth in vitro. Int J Cancer 55:630-635.

Shaw JP, Utz PJ, Durand DB, Toole JJ, Emmel EA, and Crabtree GR (1988). Identification of a putative regulator of early T cell activation genes. Science 241:202-205.

Siebenlist U, Franzoso G, and Brown K (1994). Structure, regulation and function of NF-kappa B. Annu Rev Cell Biol 10:405-455.

Sin N, Meng L, Wang MQ, Wen JJ, Bornmann WG, and Crews CM (1997). The anti-angiogenic agent fumagillin covalently binds and inhibits the methionine aminopeptidase, MetAP-2. Proc Natl Acad Sci USA 94:6099-6103.

Szabo SJ, Glimcher LH, and Ho IC (1997). Genes that regulate interleukin-4 expression in T cells. Curr Opin Immunol 9:776-781.

Takamiya Y, Friedlander RM, Brem H, Malick A, and Martuza $R L$ (1993). Inhibition of angiogenesis and growth of human nerve-sheath tumors by AGM-1470. J Neurosurg 78:470476.

Weidner N, Semple JP, Welch WR, and Folkman J (1991). Tumor angiogenesis and metastasis-correlation in invasive breast carcinoma. N Engl J Med 324:1-8.

Wink DA, Vodovotz Y, Laval J, Laval F, Dewhirst MW, and Mitchell JB (1998). The multifaceted roles of nitric oxide in cancer. Carcinogenesis 19:711-721.

Yamaoka M, Yamamoto T, Ikeyama S, Sudo K, and Fujita T (1993). Angiogenesis inhibitor TNP-470 (AGM-1470) potently inhibits the tumor growth of hormone-independent human breast and prostate carcinoma cell lines. Cancer Res 53: 5233-5236.

Yanase T, Tamura M, Fujita K, Kodama S, and Tanaka K (1993). Inhibitory effect of angiogenesis inhibitor TNP-470 on tumor growth and metastasis of human cell lines in vitro and in vivo. Cancer Res 53:2566-2570.

Zhao H and Koretzky GA (1997). Regulation of signal transduction through the $\mathrm{T}$ cell antigen receptor. $\mathrm{J}$ Lab Clin Med 130:126-131. 